\title{
Regional Variation in Shade-Dwelling Coral Assemblages of the Great Barrier Reef Province
}

\author{
Zena D. Dinesen* \\ Department of Marine Biology, School of Biological Sciences, James Cook University of North Queensland, Townsville, \\ Queensland 4811, Australia
}

\begin{abstract}
Research on shade-dwelling scleractinian corals involved the study of more than 120 caves, tunnels, and shaded overhangs from various reef types within the Great Barrier Reef Province. Study was concentrated in the Lizard Island region $\left(14^{\circ}-15^{\circ} \mathrm{S}\right)$, with comparative work in the central $\left(19^{\circ} \mathrm{S}\right)$ and especially the southern $\left(23^{\circ} \mathrm{S}\right)$ sectors of the province. Numerical classification was used to analyse patterns of distribution and association within these shade-dwelling assemblages. Analysis confirmed the existence of definite regional differences in the shade-dwelling coral fauna, with caves in the southern part of the Barrier Reef having a generally impoverished scleractinian fauna compared with that found in more northerly areas. Observations of other shade-dwelling biota suggest that at higher latitudes, certain algal groups are more successful than corals in cryptic habitats, with the algae tending to exclude their scleractinian competitors. This suggestion is borne out by records from the southwest Indian Ocean. These and other studies indicate that while there are some basic similarities between the cryptic biota from many reef regions, generalizations about the structure of the shadedwelling communities should not be made from studies within a limited area.
\end{abstract}

\section{INTRODUCTION}

Recent studies of skiophilous (shade-loving) communities in tropical and warm temperate regions have revealed the presence of a wide range of sessile benthos in cryptic habitats. The major groups represented are sponges (notably pharetronid, lithistid and silico-calcareous sponges), algae (especially coralline forms), bryozoans, brachiopods, encrusting foraminiferans, ascidians, bivalve molluscs, and various coelenterates (Laborel, 1960; Pérès and Picard, 1964; Vacelet, $1967 a, b ;$ Hartman and Goreau, 1970; Jackson et al., 1971; Pouliquen, 1971; Vasseur, 1974, 1977; Bonem, 1977; Cuffey and Fonda, 1977; Logan, 1977). The distribution of these organisms is determined principally by irradiance levels, and to a lesser extent by hydrodynamic conditions.

Various workers have emphasized the importance of cryptic or shaded environments within the reef framework (e.g. Hartman and Goreau, 1970; Jackson et

\footnotetext{
- Present address: Australian Institute of Marine Science, P.M.B. No. 3, M.S.O., Townsville, Queensland 4810, Australia

al., 1971; Jaubert and Vasseur, 1974; Bonem, 1977; Vasseur, 1977). Despite the increasing attention being focused on these cryptic habitats, very few studies have been carried out of the shade-dwelling coral fauna of Indo-Pacific reefs. The only detailed records hitherto available are those of Jaubert and Vasseur (1974) and Vasseur $(1974,1977)$ from Madagascar, in the southwest Indian Ocean.

The aim of the present study was to conduct a survey of the shade-dwelling scleractinian fauna in various sectors of the Great Barrier Reef Province. A full list of the fauna recorded (over 150 species of corals) is given in Dinesen (1980a). It is significant that the majority of these species are hermatypic forms. Of those species commonly encountered, some occur also in deep water below the range of most hermatypes, and these seem to be corals of a generally skiophilous nature. However, the cave-dwelling fauna is not only representative of a deep water coral fauna displaced into shallow, shaded conditions, at comparable low light intensities (Dinesen, 1980a). Several species appear to prefer a shallow but cryptic environment, while a considerable number of shade-dwelling species are common also in well 
illuminated areas of the 'open' reef, but are able to adapt to conditions of low light intensity. Because of the low irradiance levels, most coral colonies are small and fragile, and are restricted to a two-dimensional, encrusting or laminar growth form (Dinesen, 1980a).

This paper discusses variations in the structure and species richness of entire assemblages. Numerical classification has been used to determine whether patterns reflect differences between various types of caves and/or differences between assemblages from different reef areas, on a local and regional basis.

\section{METHODS}

\section{Field Methods and Study Areas}

Field work was concentrated on reefs in the Lizard Island region of the Great Barrier Reef Province (Fig. 1). These included fringing reefs around high islands, platform reefs, and several outer barrier reefs close to the edge of the continental shelf. Comparative work was carried out in the central part of the Province (Keeper Reef, platform reef, Townsville, 18 $45^{\prime} \mathrm{S}$. $148^{\circ} 15^{\prime} \mathrm{E}$ ), and in the southern section (Capricorn Group, platform reefs; Fig. 2).

All habitats investigated were within the reef slope, in a depth range of $4 \mathrm{~m}$ to $21 \mathrm{~m}$ below datum (approximately). Details of cave structure and dimensions were recorded. Cave size was determined from maximum measurements of height, width, and length (from aperture to back). Three basic types of cave structure were distinguished: (1) true caves: well defined recesses with definite side walls; (2) tunnels: open-ended caves, usually encountered in rather shallow water, where cavities in the reef slope connected with the reef flat; (3) overhangs: the most commonly encountered type, well shaded recesses but with one or both side walls, and/or the floor lacking, thus affording a less enclosed environment compared to true caves. For brevity, the term 'cave' is used as a general term including all these shaded environments.

Each cave was treated as a sampling unit. Since the survey sought to record as many shade-dwelling corals as possible, and the habitats investigated were often relatively small (usually $<2 \mathrm{~m}$ in largest dimension), a quadrat sampling method was not considered appropriate. Every coral in each cave was recorded, and material was removed for laboratory examination where not identifiable in the field. Specimens were identified whenever possible to species level (in the case of Montipora, apparent species were designated species numbers). However, some smaller specimens could not be identified beyond genus or family level.

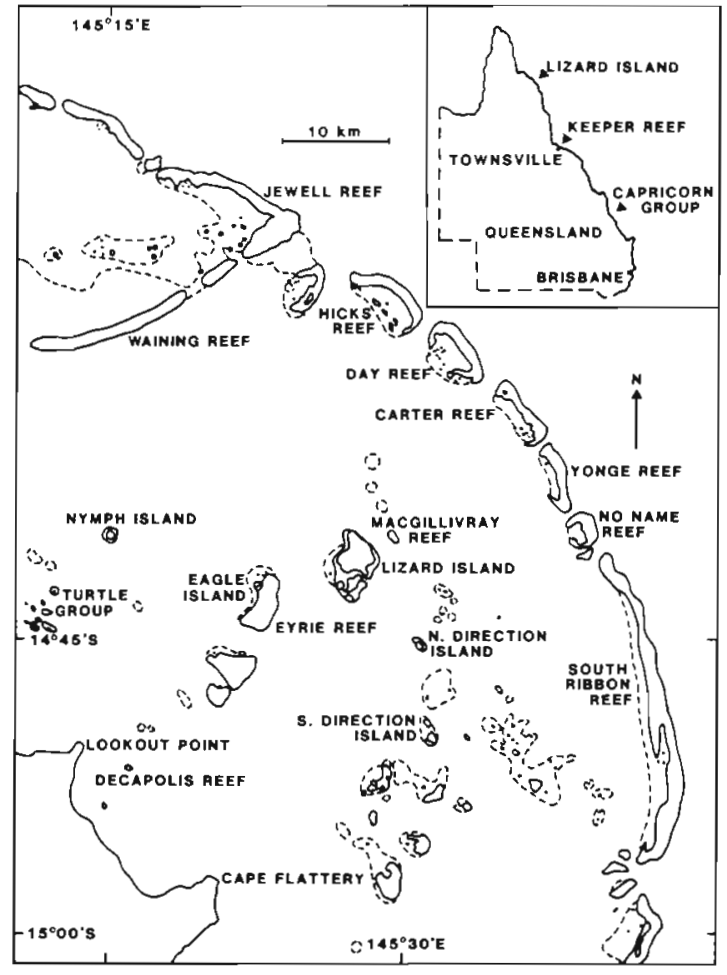

Fig. 1. Reefs of the Lizard Island region. Study sites are listed in Table 1. Inset of Queensland coast shows general locations of study areas

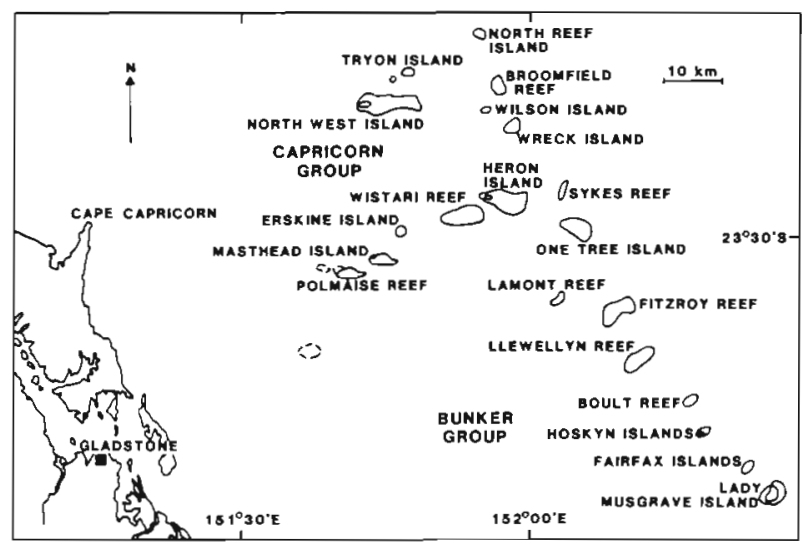

Fig. 2. Reefs of the Capricorn region. Study sites are listed in Table 1

The small ahermatypic Tubastraea and Dendrophyllia presented particular difficulties. These occurred in great abundance in some caves, and their very similar appearance suggested they belonged to a single species. These are collectively referred to as 'Tubastraea cf. aurea', to which species I believe the majority of these specimens belong, but included also in this category are a few other species of Tubastraea and small Dendrophyllia. 


\section{Analytical Methods}

Since each cave was treated as a sampling unit, the units were of variable size. Cave 'maximum volume' is positively and significantly correlated with the number of coral colonies ( $\mathrm{p}=<0.001)$ and with the number of species $(p=<0.01)$ recorded in the cave. However, the purpose of numerical classification is to generate, not to test, hypotheses (Williams, 1976). Variable size of the sampling unit is not problematic, provided that the patterns produced are not primarily a reflection of cave size (Williams, pers. comm., 1979).

A total of 100 species and species groups was used for analysis. Those species found in only 1 or 2 caves $(<2 \%$ of the total number of caves) were omitted, since many of these were apparently 'accidental' among the shade-dwelling fauna. Because of the large number of records per cave for some species, data were transformed using a $\log (n+1)$ transformation.

A 'normal' agglomerative classification to group caves was carried out using the Bray-Curtis dissimilarity measure (sensu Clifford and Stephenson, 1975). This index does not pair zero-zero matches, an important consideration since many of the species used for analysis were not commonly recorded. As similar results were obtained using the Lance-Williams fusion strategy (Lance and Williams, 1967) with $\beta=-0.25$, and Ward's method (Ward, 1963; Burr, 1968), results are presented for Ward's method only.

In interpreting cluster diagnostics, the mean values, F-ratios, and T-values (Wishart, 1975) of species within a cluster were used to identify species important in a particular cluster. High mean values indicate species well represented within a cluster; small F-ratios indicate those with comparatively low variability in the cluster, and large T-values indicate species having cluster mean values which are substantially different from the mean for the entire population. These values can be used in a comparative sense only, and should only be compared for the same level of fusion within a dendrogram. In presenting cluster diagnostics, mean values for species are shown if these were $\geqslant 0.10$, and/ or if $\mathrm{T}$-values were +0.4 or more. Large negative $\mathrm{T}$ values $(-0.4$ or higher) are also shown, and low F-ratios $(<1.0)$ are indicated for mean values of 0.10 or greater

\section{RESULTS AND DISCUSSION}

During the survey, 127 true caves, overhangs, and tunnels were investigated, from which over 3,000 coral specimens were recorded.

The major groupings of the dendrogram are shown in Fig. 3, and the composition of these clusters, in terms of the localities represented, is indicated in

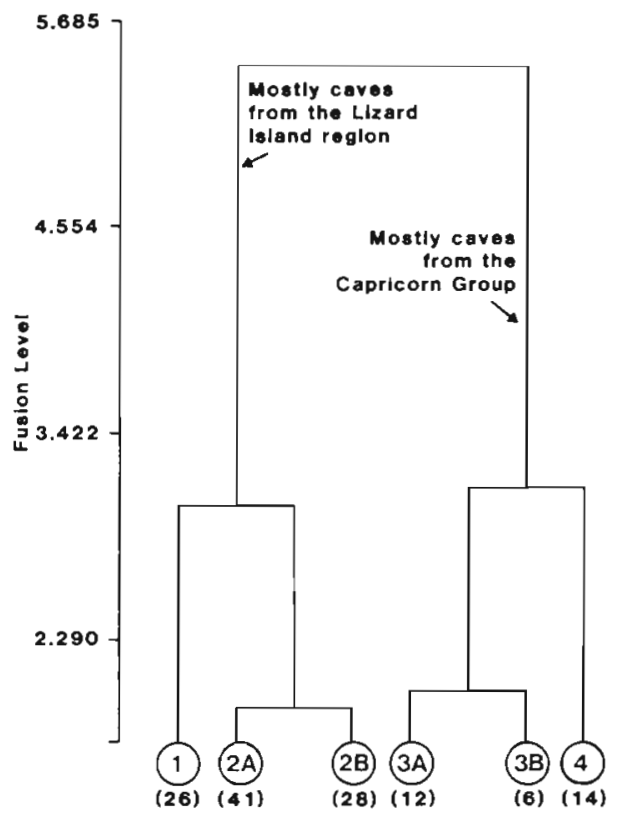

Fig. 3. Major clusters of dendrogram for 'normal' classification of shade-dwelling coral assemblages. Numbers in brackets indicate number of caves per cluster

Table 1. Cluster diagnostics are shown in Tables 2 to 4 ; and the results are discussed with particular reference to the 2 and 4 cluster levels.

Comparison of the cluster groupings with cave size showed that, despite the inclusion of some large caves from the northeast side of Lizard Island in Cluster 1 , the patterns generated are not primarily a reflection of the size of the sampling unit. Thus cave size does not seem to be influencing the cluster patterns. Furthermore, cluster patterns do not seem to be related in any way to depth. This is doubtless because, although sampling depth varied from $4 \mathrm{~m}$ to $21 \mathrm{~m}$, the decrease in light intensity with increasing depth within this range is much less than the reduction in Iight intensity caused by shading in cryptic environments.

The dendrogram falls into 2 principal groups. The first group (Clusters 1 and 2) is composed chiefly of caves from the Lizard Island region, in which a considerable range of species is well represented. The second group (Clusters 3 and 4 ) includes most of the caves from the Capricorn Group, with a definitely impoverished, and qualitatively somewhat different, coral fauna.

In Cluster 1, many species have much higher cluster mean values than in other clusters, including most of those species conspicuous in the first group at the 2 cluster level. Notable in Cluster 1 are caves from the northeast side of Lizard Island, where the fringing reefs, with numerous caves and gullies, seem to provide a particularly favourable habitat for a wide variety of shade-dwelling corals (own obs.). Also included 
Table 1. Localities represented in cluster groups in Fig. 3. Numbers indicate number of caves per locality in each cluster

\begin{tabular}{|c|c|c|c|c|c|c|c|c|c|c|c|c|c|c|}
\hline & \multicolumn{3}{|c|}{$\begin{array}{l}\text { Lizard Island } \\
\text { Group }\end{array}$} & \multicolumn{3}{|c|}{ Outer Barrier Reefs } & \multirow{2}{*}{$\begin{array}{l}\text { Eyrie } \\
\text { Reef } \\
\text { SW } \\
\text { side }\end{array}$} & \multirow{2}{*}{$\begin{array}{c}\text { Mc } \\
\text { Gil- } \\
\text { livray } \\
\text { Reef } \\
\text { SE } \\
\text { side }\end{array}$} & \multirow{2}{*}{$\begin{array}{l}\text { North } \\
\text { Direc- } \\
\text { tion } \\
\text { Island. } \\
\text { SE } \\
\text { side }\end{array}$} & \multirow{2}{*}{$\begin{array}{l}\text { Kee- } \\
\text { per } \\
\text { Reef } \\
\text { SE } \\
\text { side }\end{array}$} & \multicolumn{2}{|c|}{ Heron Reef } & \multirow{2}{*}{$\begin{array}{l}\text { Wis- } \\
\text { tari } \\
\text { Reef } \\
\text { NE } \\
\text { side }\end{array}$} & \multirow{2}{*}{$\begin{array}{l}\text { Wil- } \\
\text { son } \\
\text { Reef } \\
\text { SW } \\
\text { side }\end{array}$} \\
\hline & $\begin{array}{c}\text { NE- } \\
\text { SE } \\
\text { sides }\end{array}$ & $\begin{array}{c}\text { NW- } \\
\text { SW } \\
\text { sides }\end{array}$ & $\begin{array}{l}\text { La- } \\
\text { goon }\end{array}$ & $\begin{array}{l}\text { Outer } \\
\text { slopes } \\
\text { (Jewell, } \\
\text { Carter, } \\
\text { Yonge) }\end{array}$ & $\begin{array}{c}\text { Reef channels } \\
\text { (Carter, Yonge, } \\
\text { No Name, } \\
\text { South Ribbon) }\end{array}$ & $\begin{array}{l}\text { Back reef } \\
\text { (Yonge, } \\
\text { No Name, } \\
\text { South } \\
\text { Ribbon) }\end{array}$ & & & & & $\begin{array}{c}\mathrm{N} \\
\text { side }\end{array}$ & $\begin{array}{c}\mathrm{S} \\
\text { side }\end{array}$ & & \\
\hline Cluster 1 & 17 & & & 2 & 2 & 3 & & 1 & 1 & & & & & \\
\hline Subcluster $2 \mathrm{~A}$ & 19 & 10 & 6 & & & & 1 & 2 & & 1 & 2 & & & \\
\hline Subcluster 2B & 10 & 3 & 7 & & 1 & 2 & & 1 & 1 & 1 & 1 & 1 & & \\
\hline Subcluster $3 \mathrm{~A}$ & & 1 & & 5 & 3 & 2 & & & & & 1 & & & \\
\hline Subcluster 3B & & & & & & & & & & & 4 & 1 & 1 & \\
\hline Cluster 4 & & & & & & & & & & & 6 & 3 & 2 & 3 \\
\hline - Fringing ree & & & & & & & & & & & & & & \\
\hline
\end{tabular}

Table 2. Cluster diagnostics for 'normal' classification of shade-dwelling coral assemblages, 2 cluster level. 'F-ratios $<1.0 ;+$ and $-\mathrm{T}$-values $\geqslant 0.4-<1.0$, positive or negative

\begin{tabular}{|lcc|}
\hline Species & \multicolumn{2}{c|}{ Cluster number } \\
& $1+2$ & $3+4$ \\
\hline Stylocoeniella guentheri & 0.28 & - \\
Echinophylla aspera & 0.24 & - \\
Leptoseris mycetoseroides & 0.23 & - \\
Psammocora superficialis & 0.22 & - \\
Pachyseris speciosa & 0.22 & - \\
Cyphastrea microphthalma & 0.21 & \\
Goniastrea pectinata & 0.17 & - \\
Leptoseris scabra & 0.17 & - \\
Young pectinid & 0.15 & - \\
Pavona cf. explanulata & 0.13 & - \\
Scolymia cf. vitiensis & 0.11 & - \\
Galaxea cf. astreata & 0.11 & - \\
Lithophyllon cf. edwardsi & & - \\
Pavona varians & 0.18 & $0.11^{-}$ \\
Porites lichen & 0.19 & 0.23 \\
Tubastrea cf. aurea & 0.14 & $0.57^{+}$ \\
Seriatopora hystrix & & $0.24^{+}$ \\
Montipora sp. 8 & & $0.15^{+}$ \\
Leptoseris hawaiiensis & & $0.14^{+}$ \\
Montipora sp. 1 & & $0.13^{+}$ \\
Stylophora pistillata & & $0.07^{+}$ \\
Goniastrea australensis & & $0.06^{+}$ \\
\hline & & \\
\hline
\end{tabular}

here are caves from various reefs in the northern region. Nearly all localities represented are relatively exposed to wave action, with rather clear water, few sites being particularly sheltered.

In the second and largest cluster, many species conspicuous in Cluster 1 are well represented, though generally with somewhat lower mean values. However, a few species notable in the first cluster le.g. Leptoseris mycetoseroides, Pavona cf. explanulata, and Psammocora profundacella) are not common here, while other species (especially Porites lichen, Scolymia cf. vitiensis, Galaxea cf. astreata, and Lithophyllon cf. edwardsi) are more conspicuous in Cluster 2. Small differences in the relative abundance of a few species differentiate Subclusters $2 \mathrm{~A}$ and $2 \mathrm{~B}$. Cluster 2 contains caves from a variety of biotopes, including the majority of caves from the Lizard Island Group, plus several caves from other Barrier Reef localities.

In Cluster 3, many species notable in Clusters 1 and 2 are obviously lacking. A few corals are more evident than in other clusters, especially Seriatopora hystrix, Leptoseris hawaijensis, Montipora sp. 8, and Stylocoeniella armata. Subcluster 3A (mostly caves from the outer barrier reefs) and Subcluster 3B (Capricorn Group caves only) differ to some extent in species composition. Similarly, Cluster 4, containing only caves from the Capricorn region, has a rather impoverished faunal list, with only a few species in common with Clusters 1 and 2. A few relatively uncommon shade-dwelling corals, despite low mean values, are notable in this group, while Tubastraea cf. aurea is extremely conspicuous, having a much greater mean value than any other species in any cluster.

In many caves of the Capricorn region, this coral was very abundant. This ahermatype often flourishes in shallow water in strong current (own obs.). The strong tidal currents in this region may in part account for the abundance of Tubastraea, particularly in those overhangs allowing good flow of water. However, abundance of this coral is not considered responsible for the rather different nature of the Capricorn Group caves. Tubastraea cf. aurea occurs principally on cave ceilings, so it does not exclude corals from other cave surfaces. More importantly, some caves from further north in which this species was also very abundant are 
Table 3. Cluster diagnostics for 'normal classification of shade-dwelling coral assemblages, 4 cluster level. 'F-ratios $<1.0 ;+$ and $-T$-values $\geqslant 0.4-<1.0$, positive or negative $++\mathrm{T}$-values $\geqslant 1.0-<1.6 ;+++\mathrm{T}$-values $\geqslant 1.6$

\begin{tabular}{|c|c|c|c|c|}
\hline \multirow[t]{2}{*}{ Species } & \multicolumn{4}{|c|}{ Cluster number } \\
\hline & 1 & 2 & 3 & 4 \\
\hline Leptoseris mycetoseroides & $0.60^{++}$ & & & - \\
\hline Stylocoeniella guentheri & $0.50^{++}$ & $0.20^{\circ}$ & - & - \\
\hline Psammocora superficialis & $0.43^{+}$ & $0.14^{\circ}$ & - & \\
\hline Pavona varians & $0.35^{+}$ & $0.11^{\circ}$ & 0.16 & - \\
\hline Pachyseris speciosa & $0.29^{+}$ & 0.20 & - & - \\
\hline Cyphastrea microphthalma & $0.29^{+}$ & $0.18^{\circ}$ & - & $0.12^{\circ}$ \\
\hline Pavona cf. explanulata & $0.25^{+}$ & & & - \\
\hline Leptoseris scabra & $0.23^{+}$ & $0.15^{\circ}$ & - & - \\
\hline Physogyra lichtensteini & $0.20^{+}$ & 0.13 & - & - \\
\hline Psammocora profundacella & $0.17^{+}$ & & & \\
\hline Echinopora lamellosa & $0.09^{+}$ & & & \\
\hline Psammocora explanulata & $0.08^{+}$ & & & \\
\hline Podabacia crustacea & $0.07^{+}$ & & & \\
\hline Porites sp. 1 & $0.03^{+}$ & & & \\
\hline Echinophyllia aspera & $0.29^{+}$ & 0.22 & - & - \\
\hline Porites lichen & - & 0.23 & - & $0.17^{\circ}$ \\
\hline Goniastrea pectinata & $0.14^{\circ}$ & 0.18 & - & - \\
\hline Lithophyllon cf. edwardsi & $0.11^{\circ}$ & 0.16 & - & - \\
\hline Scolymia cf. vitiensis & & 0.12 & - & - \\
\hline Young pectiniid & $0.10^{\circ}$ & 0.16 & - & - \\
\hline Galaxea cf. astreata & & 0.13 & - & - \\
\hline Seriatopora hystrix & 0.15 & & $0.28^{+}$ & 0.21 \\
\hline Leptoseris hawailensis & $0.23^{+}$ & & $0.24^{+}$ & - \\
\hline Stylocoeniella armata & & & $0.11^{+}$ & \\
\hline Montipora sp. 13 & & & $0.08^{+}$ & \\
\hline Stylophora pistillata & & & $0.08^{+}$ & \\
\hline Leptoseris glabra & & & $0.04^{+}$ & \\
\hline Plesiastrea versipora & & & $0.03^{+}$ & \\
\hline Tubastraea cf aurea & $0.45^{+}$ & - & & $1.19^{\circ+++}$ \\
\hline Montipora sp. 8 & & & $0.11^{+}$ & $0.20^{++}$ \\
\hline Coscinaraea columna & $0.16^{+}$ & & - & $0.19^{+}$ \\
\hline Cyphastrea serailia & & & - & $0.18^{+}$ \\
\hline Montipora sp. 1 & & & & $0.18^{+}$ \\
\hline Favites abdita & & & & $0.10^{+}$ \\
\hline Goniastrea australensis & & & & $0.09^{+}$ \\
\hline Montipora sp. 9 & & & & $0.04^{+}$ \\
\hline
\end{tabular}

grouped with caves from the Lizard Island region, while a number of caves from the Heron Island area in which $T$. cf. aurea was not conspicuous are still separately grouped (in Subcluster $3 \mathrm{~B}$ ).

Although the reefs investigated in the south did not generally contain such extensive cavities as some northern reefs, the caves, overhangs, and recesses below coral heads were of a size, structure, and shadiness comparable to many of those investigated further north. The rather different nature of the shade-dwelling assemblages in the Capricorns is not, therefore, attributed to cave size or type, but rather to faunal differences which appear to be related to latitude. Such geographical differences are considered in more detail below.

About half of the caves from the outer barrier reefs
Table 4. Cluster diagnostics for 'normal' classification of shade-dwelling coral assemblages, 6 cluster level. 'F-ratios $<1.0 ;+$ and $-T$-values $\geqslant 0.4-<1.0$, positive or negative; $++T$-values $\geqslant 1.0-<1.6$. Diagnostics given only for species which serve to differentiate between pairs of subclusters

\begin{tabular}{|c|c|c|}
\hline Species & $\begin{array}{l}\text { Subcluster } \\
2 \mathrm{~A}\end{array}$ & $\begin{array}{l}\text { number } \\
2 B\end{array}$ \\
\hline Pachyseris speciosa & $0.23^{\circ}$ & 0.15 \\
\hline Stylocoeniella guentheri & $0.22^{\bullet}$ & 0.16 \\
\hline Psammocora superficialis & 0.19 & - \\
\hline Physogyra lichtensteini & 0.17 & \\
\hline Scolymia cf vitiensis & $0.14^{+}$ & \\
\hline Porites lichen & 0.13 & $0.38^{+}$ \\
\hline Cyphastrea microphthalma & 0.11 & $0.29^{+}$ \\
\hline Leptoseris mycetoseroides & - & 0.13 \\
\hline Merulina ampliata & & $0.12^{+}$ \\
\hline Young Fungia & & $0.09^{+}$ \\
\hline \multirow[t]{2}{*}{ Oxypora lacera } & & $0.08^{+}$ \\
\hline & $3 \mathrm{~A}$ & $3 \mathrm{~B}$ \\
\hline Leptoseris hawailensis & $0.37^{++}$ & \\
\hline Porites lichen & $0.34^{+}$ & 0.15 \\
\hline Stylocoeniella armata & $0.17^{+}$ & \\
\hline Leptoseris mycetoseroides & 0.12 & - \\
\hline Tubastraea cf. aurea & 0.12 & - \\
\hline Leptoseris glabra & $0.06^{+}$ & \\
\hline Plesiastrea versipora & $0.05^{+}$ & \\
\hline Montipora sp. 8 & & $0.33^{++}$ \\
\hline Montipora sp. 2 & & $0.20^{++}$ \\
\hline Stylophora pistillata & & $0.15^{++}$ \\
\hline Montipora sp. 1 & & $0.15^{++}$ \\
\hline Goniastrea australensis & & $0.01^{+}$ \\
\hline
\end{tabular}

(Subcluster 3A) are linked with those of the Capricorn Group. The species Leptoseris hawaiiensis, L. glabra, and Stylocoeniella armata are conspicuous in this subcluster, these Leptoseris species being generally more common in outer barrier situations than around Lizard Island itself (Dinesen, 1980b). However, the cluster grouping of these outer barrier caves is not due to the presence of these species, since these corals are not notable in the Heron Island region. These caves are apparently linked with those of the southern region because of a paucity of many species commonly encountered in the northern region. These outer barrier caves represent a variety of cave sizes and types from outer slope, channel, and back reef biotopes. Why these particular caves should have a rather poorer species composition compared to other caves in the northern region (including other outer barrier samples) is therefore unclear.

From Madagascar, Jaubert and Vasseur (1974) and Vasseur (1974) have distinguished various types of shaded habitats from different sectors of the reef, and a definite stratification of species within caves and overhangs. A clear zonation of skiophilous organisms has also been reported from temperate regions such as the 
Mediterranean (Laborel, 1960; Pérès and Picard, 1964). Apart from the abundance of Tubastraea cf. aurea on the ceilings of some caves, definite zones or facies within caves were not detected here (Dinesen, 1980a). There are, however, sound reasons for such lack of zonation. The Barrier Reef studies focused on a single aspect of shade-dwelling communities, the scleractinians, which are typical only of less 'obscure' (dark) cryptic environments. Moreover, in contrast to patterns found at Madagascar, the Australian studies did not reveal clear differences in the distribution of hermatypic and ahermatypic corals according to irradiance levels (Dinesen, 1980a).

Certainly, a smaller range of cryptic habitat types and conditions was encountered on the Barrier Reef than at Madagascar (hence the extensive terminology used by Jaubert and Vasseur [1974] for Madagascan caves was not required here). Nonetheless, the habitats investigated occurred in a wide variety of reef biotopes, and these cryptic habitats included some gradients in terms of illumination and hydrodynamic conditions (Dinesen, 1980a). It is significant that numerical classification has not revealed major differences between cave types, or between caves from different reef biotopes. Shade-dwelling corals presumably represent a type of assemblage to be found in shaded parts of many different reef biotopes, at least within the same region - a common assemblage which serves to link these reef biotopes, rather than differentiate between them. The primary differences between the shade-dwelling coral assemblages studied have a much broader, regional basis.

The most obvious difference between the Capricorn Group and the more northerly stations is the latitude. Latitudinal effects in terms of shorter daylength can be discounted, because reefs are flourishing in the southern region; moreover, the corals considered here are living at low light intensities. Mean temperatures and winter minima are certainly lower at the southern end of the Great Barrier Reef Province than further north (Brandon, 1973), but many shade-dwelling species living also in deep water tolerate temperatures lower than those they would experience in the Capricorns (Wells, 1957). Moreover, corals such as Leptoseris are known from marginal, subtropical areas (Dinesen, 1980 b). However, it is quite possible that temperature may influence the structure of shade-dwelling communities in an indirect manner.

There is an interesting parallel between reef caves studied at Madagascar in the southwest Indian Ocean (about $23^{\circ} \mathrm{S}$ ), and those from the Capricorn Group, at about the same latitude. In both regions, hermatypic corals are not generally abundant in cryptic habitats, although many shade-tolerant and truly skiophilous coral species are known to occur here.
The list of corals recorded from caves in the Capricorn region is indeed fairly extensive (Dinesen, 1980a), but many of these species were only rarely encountered. For example, Leptoseris mycetoseroides, L. hawaiiensis, Lithophyllon cf. edwardsi, Echinophyllia aspera, Pavona varians, and Psammocora profundacella, frequently recorded in the northern Barrier Reef region, were found in only one or a few southern caves. Other corals, such as Pachyseris speciosa, Galaxea clavus (= Galaxea cf. astreata), Scolymia, and Physogyra, were not found in caves in the Capricorn Group, but they are known to occur on these reefs (Stephenson and Wells, 1956; Woodhead and Domm, unpubl.). Various shade-dwelling species, including Stylocoeniella guentheri, Pachyseris speciosa, Porites lichen, Cyphastrea microphthalma, Goniastrea pectinata, and species of Leptoseris, pectiniids, and solitary mussids, have been reported from Tuléar by Pichon (1978). They were not, however, encountered by Jaubert and Vasseur in their studies of skiophilous communities at Madagascar.

In most of the caves in the Capricorn region, certain groups of algae were very conspicuous. These included fleshy green algae (aff. Anadyomene), and especially the red coralline alga Peyssonnelia, which was often extremely abundant, covering a high proportion of cave surfaces. Although present further north, these algae were rarely observed there in such abundance. Significantly, at Tuléar, hermatypic corals were notable only in those parts of the algal-dominant biocoenosis' in which crustose coralline algae were also conspicuous (Vasseur, 1974). In those facies where non-crustose coralline algae and fleshy algae were dominant, corals were apparently less conspicuous.

These observations suggest that shade-dwelling corals in less tropical reef regions are less common in cryptic habitats than in lower latitude reef areas. It seems, therefore, that with increasing latitude and hence cooler water, certain algal groups may be more successful than corals in these habitats, with the algae tending to exclude their scleractinian competitors. Further evidence is, of course, required to confirm this view. Although many fast-growing species typical of the 'open' reef are excluded from these cryptic habitats, the environment nevertheless supports a wide range of organisms which may compete with one another for space. Competition among cryptic organisms has been documented previously (Glynn, 1973; Cuffey and Fonda, 1977; Jackson, 1977), and is further suggested by the very high cover achieved by some shade-dwelling species (Hartman and Goreau, 1970; Jackson et al., 1971; Jaubert and Vasseur, 1974).

Differences have also been found between assemblages of cryptic bryozoans from nearshore and offshore reefs, and between such bryozoan assemblages 
in the Bahamas compared to those at Bermuda (Cuffey and Fonda, 1977). All these studies of cryptic communities therefore indicate that while there are doubtless some basic similarities between the cryptic biota from many regions, generalizations about the structure of shade-dwelling communities should not be made from studies within a single geographical area.

Acknowledgements. I am very grateful to the following people for advice or assistance during this research: Dr $M$. Pichon, for advice and encouragement as supervisor of my Ph. D. research; Mr W. Nash, Mr R. Moss, the crew of the R. $V$ 'James Kirby', and the staff of Lizard Island and Heron Island Research Stations, for assistance in the field; Dr. M. Pichon, Dr. J. Veron, Mr. H. Moll, and Dr C. Wallace, for assistance with identification of material; Dr. W. Williams and Dr. P. Arnold, for advice on data processing; the Drapers Company, London, for the research scholarship which allowed me to carry out this work; and the Great Barrier Reef Committee, for additional funds for field work

\section{LITERATURE CITED}

Bonem, R. M. (1977). Comparison of cavities and cryptic biota in modern reefs with those developed in lower Pennsylvanian (Morrowan) bioherms. In: Proceedings of the Third International Coral Reef Symposium, Vol. 1. University of Miami, Florida, pp. 75-80

Brandon, D. E. (1973). Waters of the Great Barrier Reef Province. In: Jones, O. A., Endean, R. (eds.) Biology and geology of coral reefs, Vol. 1, Geology 1. Academic Press, New York, pp. 187-232

Burr, E. J. (1968). Cluster sorting with mixed character types. I. Standardization of character values. Aust. Comput. J. 1: 97-99

Clifford, H. T., Stephenson, W. (1975). Introduction to numerical taxonomy, Academic Press, London

Cuffey, R. J., Fonda, S. S. (1977). Cryptic bryozoan species assemblages in modern coral reefs off Andros and Eleuthera, Bahamas. In: Proceedings of the Third International Coral Reef Symposium, Vol. 1 University of Miami, Florida, pp. 81-86

Dinesen, Z. D. (1980a). Some ecological aspects of coral assemblages in the Great Barrier Reef Province. Ph. D. thesis, James Cook University of North Queensland

Dinesen, Z. D. (1980b). A revision of the coral genus Leptoseris (Scleractinia: Fungiina: Agariciidae). Mem. Qd Mus. 20 (1): 181-235

Glynn, P. W. (1973). Aspects of the ecology of coral reefs in the western Atlantic region. In: Jones, O. A., Endean, R. (eds.) Biology and geology of coral reefs, Vol. 2, Biology 1. Academic Press, New York, pp. 271-324

Hartman, W D., Goreau, T. F. (1970). Jamaican coralline sponges: their morphology, ecology and fossil relatives. Symp. zool. Soc. Lond. 25: 205-243

Jackson, J. B. C. (1977). Habitat area, colonization and development of epibenthic community structure. In: Keegan, B. F., Ceidigh, P. O., Boaden, P. J. S. (eds.)
Biology of benthic organisms. 11th European Symposium on Marine Biology, Galway, Ireland, October 1976. Pergamon Press, Oxford, pp. 349-358

Jackson, J. B. C., Goreau, T F., Hartman, W. D. (1971). Recent brachiopod-coralline sponge communities and their paleoecological significance. Science, N. Y 173:623-625

Jaubert, J. V., Vasseur, P. (1974). Light measurements: duration aspect and the distribution of benthic organisms in an Indian Ocean coral reef (Tuléar, Madagascar). In: Proceedings of the Second International Coral Reef Symposium, Vol. 2. Great Barrier Reef Committee, Brisbane, pp. $127-142$

Laborel, J. (1960). Contribution a l'étude directe des peuplements benthiques sciaphiles sur substrat rocheux en Méditerranée. Recl Trav. Stn mar Endoume 33: 117-173

Lance, G. N., Williams, W. T. (1967). A general theory of classificatory strategies. I. Hierarchical systems. Comput. J. 9: $373-380$

Logan, A. (1977). Reef-dwelling articulate brachiopods from Grand Cayman, B. W. I. In: Proceedings of the Third International Coral Reef Symposium, Vol. 1. University of Miami, Florida, pp. 87-93

Pérès, J. M., Picard, J. (1964). Nouveau manuel de bionomie benthique de la Mer Méditerranée. Recl Trav. Stn mar Endoume 47: 5-137

Pichon, M. M. (1978). Recherches sur les peuplements à dominance danthozoaires dans les récifs coralliens de Tuléar (Madagascar). Atoll Res. Bull. 222: 1-447

Pouliquen, L. (1971 [1972]). Les spongiaires des grottes sousmarines de la région de Marseille: Ecologie et systématique. Téthys 3: 717-758

Stephenson, W., Wells, J. W. (1956). The corals of Low Isles, Queensland; August 1954. Pap. Dep. Zool. Univ. Qd 1: $1-59$

Vacelet, J. (1967a). Quelques éponges pharétronides et 'silico-calcaires' de grottes sousmarines obscures. Recl Trav. Stn mar. Endoume 58 (Bull. 42): 121-132

Vacelet, J. (1967b). Descriptions d'éponges pharétronides actuelles des tunnels obscurs sousrécifaux de Tuléar (Madagascar). Recl Trav. Stn mar Endoume 6 (Suppl.): 36-62

Vasseur, P. (1974). The overhangs, tunnels and dark reef galleries of Tuléar (Madagascar) and their sessile invertebrate communities. In: Proceedings of the Second International Coral Reef Symposium, Vol. 2. Great Barrier Reef Committee, Brisbane, pp. 143-159

Vasseur, P. (1977). Cryptic sessile communities in various coral formations on reef flats in the Tuléar vicinity (Madagascar). In: Proceedings of the Third International Coral Reef Symposium, Vol. 1. University of Miami, Florida, pp. 95-100

Ward, J. H. (1963). Hierarchical grouping to optimize an objective function. J. Am. statist. Ass. 58: 236-244

Wells, J. W. (1967). Coral reefs. Mem. geol. Soc. Am. 67: $609-631$

Williams, W T. (ed.) (1976). Pattern analysis in agricultural science, CSIRO, Melbourne, and Elsevier, Amsterdam

Wishart, D. (1975). CLUSTAN IC Manual, Computer Centre, University College, University of London, London

Woodhead, P. M. J., Domm, S. (unpublished Ms.) Corals of the Capricorn Group, including One Tree Island

This paper was presented by Dr. D. Kühlmann; it was accepted for printing on October 30,1981 